\title{
Venereal Disease Contact Investigation
}

\author{
-A Combined Military-Civilian Program-
}

\author{
BY NICHOLAS J. FIUMARA, M.D., M.P.H., JACK SEGAL, M.D., and JACK JOLLY, B.S.
}

$\mathrm{T}$ HE CON'TROL of venereal diseases among military personnel is a joint function of military and civilian authorities. A military program aimed at the prevention and control of venereal diseases will be effective only to the degree of joint participation of the civilian and military partners. Each group must assume responsibility in certain areas, but the program should be integrated in its conception and execution. A brief review will delineate the areas of responsibility of both the civilian and military authorities.

\section{Military Program}

The activities of the armed forces may be conveniently divided into two phases-the program for prevention and the program for control of the venereal diseases.

\section{Preventive Program}

1. Education. The objective of this part of the program is not only to motivate the individual serviceman to avoid exposure but also to strengthen and reinforce his belief in the fundamental truths of decency and morality, to

Dr. Fiumara is director, division of venereal disease, Massachusetts Department of Public Health, and lecturer, Boston University School of Medicine; Colonel Segal is commanding officer of the U.S. Army Hospital, Fort Devens, Mass.; and Mr. Jolly is health program representative for the New England Area Regional Office, Public Health Service.

Vol. 68, No. 3, March 1953 the end that he may retain his own self-respect, attain a mature and balanced personality, and build a sound basis for marriage, family life, and constructive community life. The character guidance program has been devised to accomplish this purpose.

2. Prophylaxis. Mechanical, chemical, and antibiotic methods of prevention are available for those servicemen who, for one reason or another, expose themselves to possible infection. They fail to appreciate the inherent limitations and effectiveness of these measures. Because of the conditions under which they are used-the inopportuneness, the messiness, the alcoholic inhibition factor, the time factorthese and many other considerations, it is imperative to de-emphasize prophylactic measures as a major part of the preventive program.

3. Measures are taken to maintain morale through effective leadership, a thorough understanding of the over-all objective of the services (why we are fighting), a fair distribution of the work, proper job placement and utilization, and adequate recreation.

\section{Control Program}

Control measures are designed to detect and treat cases of venereal diseases as soon as possible after they are contracted. The control principles used by the military authorities are similar to those used in civilian practice :

1. Screening tests through periodic examination of the serviceman.

2. Voluntary reporting to a medical officer should a serviceman suspect that he may have acquired a venereal disease. 
3. Contact investigation, to elicit the names, addresses, and circumstances surrounding each exposure with all contacts and with those persons exposed by the patient, within the maximum incubation period of the disease, from date of onset of the patient's symptoms to the moment treatment could be expected to be effective (1). Contact investigation also aims at the re-education and orientation of the patient.

\section{Complementary Civilian Program}

The civilian program, like that of the military, can be divided logically into two phasesmeasures aimed at prevention and at control.

\section{Preventive Program}

1. The civilian community is responsible for seeing to it that by the time an individual has reached military age, he has, through proper home training, religious instruction, and community socialization, developed a mature and balanced personality and a self-disciplined character.

2. The repression of commercialized and clandestine prostitution is the responsibility of civil law enforcement authorities (E).

3. The civilian community should also provide an environment, during the off-duty hours of military personnel, which is not only safe and wholesome, but which integrates the recreational and social activities of the servicemen with those of the community's civilian components.

\section{Control Program}

1. Participation of the civilian health department in the military venereal disease control program implies that the former maintains and operates an efficient and well-ordered venereal disease control program. This should include adequate case-finding, diagnostic, treatment, and case-holding procedures for the venereal diseases for the civilian population (2).

2. Contacts of military personnel should be investigated with dispatch. Once these contacts have been found and examined, a report of their medical disposition should be forwarded without delay by civilian health departments to the proper military authorities.

3. Military personnel who are contacts of in- fected civilians should be reported to the appropriate medical commands of the military services, and the results of the medical examination of the named servicemen forwarded by the military authorities to the reporting civilian agency.

4. Civilian venereal disease control officers should actively participate in the work of the armed forces disciplinary control boards to safeguard the health, welfare, and morals of armed forces personnel.

\section{Joint Program}

These, in brief, are the general duties and responsibilities of both military and civilian authorities in their joint program for venereal disease control. Failure of one of the contracting parties to live up to his end of the agreement forecasts a pessimistic future for the military control program. However, there are times when, because of the exigencies of the moment, some of the services cannot be adequately carried out. Such a situation arose in Massachusetts. The demands of the United Nations in Korea, requiring the transfer of trained and key personnel to the front, left Fort Devens without trained venereal disease interviewers. As the rotation of men continued, this lack was sorely felt. Like many military stations in the United States, the venereal disease rate at Fort Devens did not require the fulltime services of a venereal disease interviewer. However, there was no question that the military venereal disease control program would profit from the services of such an individual. Therefore, the services of three well-trained nurse venereal disease epidemiologists from the Massachusetts Department of Public Health were offered and accepted. These nurses carry out a specialized program in venereal disease control and operate from venereal disease clinics located approximately 10 miles from the post. From these clinics, the epidemiologists carry out their venereal disease control activities in a given number of communities surrounding their clinics. This pattern exists throughout the State, where there are 24 clinics located in general hospitals (with 3 exceptions), each with an epidemiologist, so that complete coverage of all communities in the State is assured. 
The experiences of the Fort Devens hospital since September 1951, when the services of the epidemiologists were made available, to February 1,1952 , a period of 5 months, are summarized in this paper. The station hospital still has the services of these nurses and more complete reports will be given as data are accumulated.

\section{Methods}

A simple but effective system of contact investigation has been set up. The out-patient department facilities of the station hospital at Fort Devens have been so arranged that patients referred to the venereal disease clinics or voluntarily reporting for examination are seen in the morning. After an appropriate examination, the necessary laboratory tests are performed. Reports of the laboratory examinations are ready by 1:00 p. m., in time for the afternoon clinic. Patients who were examined in the morning are requested to return in the afternoon, when, with all laboratory reports available, a definitive diagnosis can be made. Once the diagnosis has been established and confirmed by laboratory tests, the patient is interviewed by the nurse epidemiologist in a private room at the clinic. The schedule for the nurses has been so arranged that, each afternoon 5 days a week, one epidemiologist is detailed for interviewing at the clinic. Two of the nurses report two afternoons a week, and a third at one afternoon session. If no patients are examined in the morning, the nurse on call for that afternoon is notified by phone, thus releasing her for other duties.

\section{Function of the Epidemiologists}

The epidemiologists have a threefold function. Their primary responsibility is to ascertain the identity and description of contacts, as well as circumstances surrounding the exposures, for example, place and date of encounter and exposure, and relationship of the contacts to the patient. This information is given to a corpsman, who transcribes it on the military epidemiological report forms (PHS-1421 VD) and routes copies of the form to the health departments of the States where the contacts are reportedly located, or to city health departments when so indicated by military regulations.

The second responsibility of the epidemiologists, carried out during the interview, is to re-educate and reorient the patient.

Equally important is the third undertaking of the nurse, the proper indoctrination and individual training of the hospital corpsmen.

The names and addresses of all contacts are obtained whenever possible, regardless of whether they may be in Massachusetts or from other States or countries. The service is comprehensive. However, for contacts most likely to be found in Massachusetts, the nurse epidemiologists transcribe the contact data on Massachusetts forms in addition to the military reports. Copies of the Massachusetts epidemiological forms are sent directly to the epidemiologist in whose district the contact may be located, and the original copy, as well as the military forms, are sent directly to the Massachusetts Department of Public Health, division of venereal diseases. When complete identifying information is obtained, the data is immediately telephoned to the central office where it is the responsibility of the division staff to locate the appropriate nurse in the field and relay the information to her. The forms follow in routine fashion.

Such is the system which has been arrangedsimple yet effective.

\section{Results}

During the period of January to August 1951, inclusive, a total of 175 cases of venereal disease was diagnosed at the United States Army Hospital, Fort Devens, Mass. There were 159 patients with gonorrhea and 16 infected with syphilis. Of the latter, 12 were in the primary or secondary stages (lesion syphilis) and 4 in the early latent stage. The corpsmen were able to elicit the names of 1.13 contacts per patient with gonorrhea and of 1.58 contacts per patient with lesion syphilis (table 1 ).

However, during the first 5 months of this study, September 1951 through January 1952, when infected patients were interviewed by the nurse epidemiologists from the Massachusetts Department of Public Health, division of venereal diseases, a total of 136 cases of venereal 
disease was diagnosed at Fort Devens. Of this number, 113 represented cases of gonorrhea, 21 syphilis, and 2 granuloma inguinale. Of the syphilis patients, 13 were in the primary or secondary stages, 6 had latent syphilis, and 2 were in the late stages. The nurses were able to obtain 1.29 contacts per patient with gonorrhea; the contact-patient index for lesion syphilis was 3.46 (table 1 ).

\section{Table 1. Results of confact investigation at Fort Devens, Mass.}

\begin{tabular}{|c|c|c|c|c|}
\hline \multirow{2}{*}{ Number of cases } & \multicolumn{2}{|c|}{ Gonorrhea } & \multicolumn{2}{|c|}{$\begin{array}{l}\text { Primary and } \\
\text { secondary } \\
\text { syphilis }\end{array}$} \\
\hline & $\begin{array}{c}\text { Hos- } \\
\text { pital } \\
\text { corps- } \\
\text { men }\end{array}$ & Nurses & $\begin{array}{c}\text { Hos- } \\
\text { pital } \\
\text { corps- } \\
\text { men }\end{array}$ & Nurses \\
\hline $\begin{array}{l}\text { Number of patients ex- } \\
\text { amined } \\
\text { Number of contacts } \\
\text { named } \\
\text { With complete in- } \\
\text { formation } \\
\text { Percent with com- } \\
\text { plete information } \\
\text { Found and examined } \\
\text { Percent found and } \\
\text { examined } \\
\text { Contact-patient index } \\
\text { Epidemiological index } \\
\text { Brought-to-treatment in- } \\
\text { dex }\end{array}$ & $\begin{array}{r}159 \\
179 \\
66 \\
36.9 \\
61 \\
34.1 \\
1.13 \\
.33 \\
1.31\end{array}$ & $\begin{array}{r}113 \\
146 \\
74 \\
50.7 \\
63 \\
43.2 \\
1.29 \\
.47 \\
2.44\end{array}$ & $\begin{array}{r}12 \\
19 \\
4 \\
21.1 \\
10 \\
52.6 \\
1.58 \\
.17 \\
.08\end{array}$ & $\begin{array}{l}42.2 \\
\text { 3. } 46\end{array}$ \\
\hline
\end{tabular}

${ }^{1}$ Includes 15 treated on suspicion.

${ }^{2}$ Includes 26 treated on suspicion.

\section{Military Interviewers}

Gonorrhea. The military interviewers were able to elicit identifying information on 179 contacts of the 159 patients with gonorrhea (table 1). The contact data were examined and it was concluded that complete identifying information had been obtained on 66 (36.9 percent). The information, whether complete or incomplete, was transcribed on the military epidemiological report forms and sent to the States in which the contacts were most likely to be found. As a result of the information furnished to the States, including Massachusetts, 61 (34.1 percent) of the contacts were found and examined. The epidemiological index was 0.33 since 53 of the contacts were found to be infected. When the contact information was adequate, 56.1 percent of the contacts were located and examined in contrast to the 21.2 percent who were located when the contact data were incomplete.

Lesion Syphilis. There were 12 patients with primary or secondary syphilis and the military interviewers were able to obtain information on 19 of their contacts, a contactpatient ratio of 1.58 (table 1 ). The contact data were deemed complete or adequate in 4 (21.1 percent) and incomplete in 15 (78.9 percent) cases. The contact information was sent to the respective States and 10 (52.6 percent) of the contacts were found and examined, 5 in Massachusetts and 5 in other States. The epidemiological index was 0.17 . When contact information was complete 75.0 percent of the contacts were located and examined in contrast to the 46.7 percent who were found when the information was incomplete.

\section{Specialized Nurse Interviewers}

Gonorrhea. During the period covered by this report the nurses interviewed 113 patients with gonorrhea and obtained information on 146 contacts, a contact-patient index of 1.29 (table 1). This is not very different from the 1.13 contact-patient ratio obtained by the military interviewers, and the difference between the two is not statistically significant. However, when the adequacy of the contact data and the number of contacts found and examined are studied, one finds a significant difference, for 50.7 percent of the contact information obtained by the nurses was complete and 43.2 percent of the contacts were found and examined. The epidemiological index for all States for gonorrhea was 0.47 .

Lesion Syphilis. There were 13 patients with primary or secondary syphilis and the nurses obtained the names of 45 contacts, a contact-patient ratio of 3.46 (table 1). This is in contrast to a contact-patient index of $1.58 \mathrm{ob}-$ tained by the military interviewers. The contact data were considered complete in 25 (55.6 percent) cases and incomplete in 20 (44.4 percent). These data were sent to the various States in the routine manner and 19 (42.2 percent) were located and examined. The epidemiological index was 0.38 . 
Table 2. Venereal disease contacts of military personnel at Fort Devens, Mass., investigated by the State of Massachusetts and by other States

\begin{tabular}{|c|c|c|c|c|c|c|c|c|c|c|c|c|c|c|c|c|}
\hline \multirow{4}{*}{ Number of cases } & \multicolumn{8}{|c|}{ Massachusetts } & \multicolumn{8}{|c|}{ Other States } \\
\hline & \multicolumn{4}{|c|}{ Gonorrhea } & \multicolumn{4}{|c|}{$\begin{array}{l}\text { Primary and sec- } \\
\text { ondary syphilis }\end{array}$} & \multicolumn{4}{|c|}{ Gonorrhea } & \multicolumn{4}{|c|}{$\begin{array}{l}\text { Primary and sec- } \\
\text { ondary syphilis }\end{array}$} \\
\hline & \multicolumn{2}{|c|}{$\begin{array}{c}\text { Hospital } \\
\text { corps- } \\
\text { men }\end{array}$} & \multicolumn{2}{|c|}{ Nurses } & \multicolumn{2}{|c|}{$\begin{array}{c}\text { Hospital } \\
\text { corps- } \\
\text { men }\end{array}$} & \multicolumn{2}{|c|}{ Nurses } & \multicolumn{2}{|c|}{$\begin{array}{l}\text { Hospital } \\
\text { corps- } \\
\text { men }\end{array}$} & \multicolumn{2}{|c|}{ Nurses } & \multicolumn{2}{|c|}{$\begin{array}{c}\text { Hospital } \\
\text { corps- } \\
\text { men }\end{array}$} & \multicolumn{2}{|c|}{ Nurses } \\
\hline & 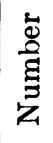 & 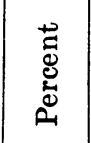 & 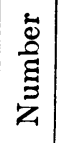 & 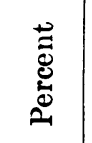 & 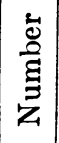 & 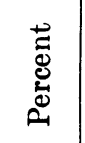 & 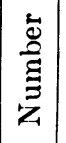 & 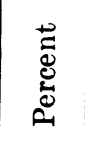 & 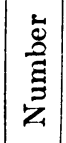 & 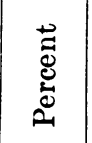 & 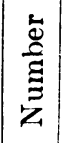 & 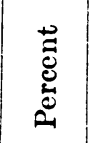 & $\begin{array}{c}\stackrel{\tilde{J}}{0} \\
\stackrel{0}{\Xi} \\
\stackrel{3}{z}\end{array}$ & 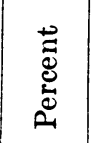 & 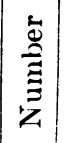 & 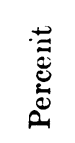 \\
\hline Total cases & 71 & 100.0 & 52 & 100.0 & 8 & 100.0 & 18 & 100.0 & 108 & 100.0 & 94 & 100.0 & 111 & 100.0 & 27 & 100.0 \\
\hline $\begin{array}{l}\text { Complete inform } \\
\text { Located and exa } \\
\text { Not infected... }\end{array}$ & & \begin{tabular}{r|}
14.1 \\
43.7 \\
2.8 \\
\end{tabular} & $\begin{array}{r}14 \\
37 \\
0 \\
\end{array}$ & \begin{tabular}{r|}
26.9 \\
71.2 \\
0.0 \\
\end{tabular} & $\begin{array}{l}0 \\
5 \\
5 \\
\end{array}$ & $\begin{array}{r}0.0 \\
62.5 \\
62.5 \\
\end{array}$ & $\begin{array}{r}6 \\
11 \\
7\end{array}$ & $\begin{array}{l}33.3 \\
61.1 \\
38.9 \\
\end{array}$ & $\begin{array}{r}56 \\
30 \\
6 \\
\end{array}$ & \begin{tabular}{r|}
51.9 \\
27.8 \\
5.6 \\
\end{tabular} & \begin{tabular}{l|}
60 \\
26 \\
10
\end{tabular} & \begin{tabular}{l|}
63.8 \\
27.7 \\
10.7
\end{tabular} & $\begin{array}{l}4 \\
5 \\
3\end{array}$ & $\begin{array}{l}36.4 \\
45.5 \\
27.3\end{array}$ & $\begin{array}{r}19 \\
8 \\
7\end{array}$ & $\begin{array}{l}70.4 \\
29.6 \\
25.9\end{array}$ \\
\hline Infected & 29 & 40.9 & 37 & 71.2 & 0 & 0.0 & 4 & $\overline{22.2}$ & 24 & 22.2 & 16 & 17.0 & 2 & 18.2 & 1 & 3. 7 \\
\hline $\begin{array}{l}\text { New case } \\
\text { Already under treatment } \\
\text { Treatment on suspicion }\end{array}$ & $\begin{array}{r}14 \\
0 \\
15 \\
\end{array}$ & & \begin{tabular}{r|r}
13 & \\
24 \\
\end{tabular} & & $\begin{array}{l}0 \\
0 \\
0 \\
\end{array}$ & & $\begin{array}{l}\mathbf{4} \\
0 \\
0\end{array}$ & 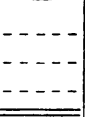 & \begin{tabular}{r|}
21 \\
3 \\
0 \\
\end{tabular} & 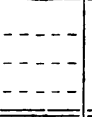 & \begin{tabular}{r|}
11 \\
3 \\
2 \\
\end{tabular} & 等 & $\begin{array}{l}1 \\
1 \\
0\end{array}$ & $\ldots$ & $\begin{array}{l}1 \\
0 \\
0 \\
0\end{array}$ & $\overline{-1}$ \\
\hline Not examined & 40 & 56.3 & 15 & 28. 8 & 3 & 37.5 & 7 & 38.9 & 78 & 72.2 & 68 & 72.3 & 6 & $\overline{54.5}$ & $\mid 19$ & 70.4 \\
\hline $\begin{array}{l}\text { Insufficient information } \\
\text { Cannot locate } \\
\text { No disposition }\end{array}$ & $\begin{array}{l}19 \\
21\end{array}$ & & $\begin{array}{r}4 \\
11 \\
0\end{array}$ & & $\begin{array}{l}\mathbf{0} \\
\mathbf{3} \\
\mathbf{0}\end{array}$ & & $\begin{array}{l}1 \\
6 \\
0\end{array}$ & & $\begin{array}{l}31 \\
21 \\
26\end{array}$ & & $\begin{array}{l}14 \\
18 \\
36\end{array}$ & & 1 & & 9 & - \\
\hline
\end{tabular}

\section{Conclusions}

Contact interviewing is a highly specialized art requiring the services of well-trained personnel. Experiences of the Massachusetts State Health Department with the Fort Devens hospital have been very satisfactory. They suggest that other Army hospitals might well consider the advisability of a closer liaison with civilian health authorities, particularly if welltrained military interviewers are not available. More careful attention to contact investigation is needed.

\section{Summary}

This paper summarizes the basic principles of a military venereal disease control program. It emphasizes that adequate control measures must have complementary action on the part of civilian authorities. It further describes the unique experiences of a State health department in not only interviewing military patients for contacts but also engaging in the training of military hospital corpsmen in the highly specialized art of contact interviewing.

The study points up the need for highly trained personnel in carrying out contact interviewing, by comparing the results of interviewing by relatively untrained versus trained people. The hospital corpsmen who have had little training in interviewing were able to obtain 1.13 contacts per patient with gonorrhea and 1.58 contacts for lesion syphilis. In contrast, the nurses obtained 1.29 contacts for gonorrhea and 3.46 contacts for syphilis. With the information supplied by the military interviewers, civilian health departments were able to locate 34.1 percent of the gonorrheal contacts and 52.6 percent of the syphilis contacts. On the other hand, information supplied by the nurses resulted in 43.2 percent of the gonorrheal contacts and 42.2 percent of the syphilis contacts being found in spite of the fact that no disposition has been reported on 24.7 percent of the gonorrheal contacts and 17.8 percent of 
the syphilis contacts as compared with 14.5 percent of gonorrheal contacts with no disposition from military interviewers and 10.5 percent for syphilis contacts.

Of striking importance was the epidemiological index. From information supplied by the hospital corpsmen, the epidemiological index was 0.33 for gonorrhea and 0.17 for syphilis: In contrast, the epidemiological indexes from information supplied by the nurses were 0.47 for gonorrhea and 0.38 for syphilis.
One of the important points brought out in this study is the obvious necessity for the States to improve their contact investigational activities (table 2).

\section{REFERENCES}

(1) Fiumara, Nicholas J.: Ten principles of VD contact interviewing. J. Social Hyg. 35: 322-327 (1949).

(2) The Eight Point Agreement of 1948. J. Ven. Dis. Inform. 31: 199-200 (1950).

\section{Public Health Training Courses}

In the spring of 1953 , refresher training courses in the principles and practices of laboratory diagnostic methods and field training courses in insect and rodent control will be offered by the Communicable Disease Center, Public Health Service.

Laboratory subjects will include general bacteriology, enteric bacteriology, tuberculosis, virus diseases, rabies, parasitology, medical mycology, veterinary mycology, and microbiology for public health nurses. Instruction covers lectures, laboratory exercises, demonstrations, audio-visual aids, and group discus- sions. Laboratory training courses will be offered throughout 1953 .

Laboratory personnel of State and local health departments, Federal agencies, and nonprofit institutions are eligible for the laboratory series. Applications should be submitted through the appropriate State health officer or, for Federal personnel, through the bureau or division chief, and forwarded to: Medical Officer in Charge, Communicable Disease Center, Public Health Service, Box 185, Chamblee, Ga., Attention: Laboratory Training Services. Requests for application forms and a bulletin describing the 1953 training series should be sent to the same address.

Personnel in State and local health departments and the Public Health Service are eligible for the courses in insect and rodent control. Persons from other organizations will be accepted if facilities permit. Applications should be made through the sponsoring agency to: Medical Officer in Charge, Communicable Disease Center, Public Health Service, 50 Seventh Street NE, Atlanta 5, Ga., Attention: Chief, Training Branch. Both series of courses are scheduled as follows :

\section{Insect and Rodent Control}

March 23-April 3: Rodent control. April 6-17: Insect control.
April 20-May 1: Rodent control. May 4-15: Insect control.

\section{Laboratory}

March 16-27 : Laboratory diagnosis of virus diseases.

March 16-27: Laboratory methods in medical mycology-cutaneous fungi (part 1).

March 16-27 : Laboratory diagnosis of tuberculosis.

March 30-April 3: Laboratory diagnosis of tuberculosis (directors' course).

March 30-April 10: Laboratory methods in medical mycology-subcutaneous and systemic fungi (part 2). NoTE: Part 1, cutaneous fungi course, or equivalent education or experience, is a prerequisite.

April 6-10: Laboratory diagnosis of bacterial diseases (directors' course).

April 13-17: Laboratory diagnosis of parasitic diseases (directors' course).

April 13-17 : Laboratory diagnosis of rabies.

May 4-8: Microbiology for public health nurses. 